\title{
Faktor Risiko Kepatuhan Kemoterapi pada Pasien Kanker Payudara
}

\author{
Halimatussakdiah ${ }^{1}$, Junardi ${ }^{2}$ \\ ${ }^{1,2}$ Jurusan Keperawatan Politeknik Kesehatan Aceh \\ Email: atus_halimah@yahoo.com
}

\begin{abstract}
Risk Factor of The Obedience to Chemotherapy on Breast Cancer Patients. The prevalence of cancer in Indonesia is significantly high. Based on data (Rikesdas) in 2013, it showed that the prevalence of cancer is 1,4 per 1000 people or approximately 330.000 people. The most popular cases faced by women is chest and cervix cancer. Data has shown that $75 \%$ of breast cancer had chemotherapy. The result of studies shows that more than $60 \%$ of chemotherapy patient caused hair fall, darken-nail, queasy, and loss appetite. The aim of this study was to find out factors related to the obedience to chemotherapy on breast cancer patients in wardThursina II BLUD Zainal Abidin Hospital Banda Aceh in 2017. This research was conducted from 1 April to 30 May 2017. This type of research was the correlation with crossectional study design approach. The population of the study included all of the breast cancer patients who were having chemotherapy. The technique of sampling used was accidental sampling that involved 65 participants. Data were analyzed using Chi-Square Test. The result of the study showed that there was a relationship self-concept and chemotherapy obedience ( $p$-value $=0,013)$; expense and chemotherapy obedience ( $p$-value $=0,036)$; family support and chemotherapy obedience ( $p$-value $=0,002$ ); side-effects and chemotherapy obedient (p-value=0,007). It is hoped that all the employee in BLUD dr.Zainal Abidin Hospital Banda Aceh can improve nursing management and enhance operational standard procedure on chemotherapy for patients, especially for breast cancer patients.
\end{abstract}

Keywords: Obedience, Chemotherapy, Breast cancer

\begin{abstract}
Abstrak: Faktor Risiko Kepatuhan Kemoterapi pada Pasien Kanker Payudara. Di Indonesia prevalensi penyakit kanker juga cukup tinggi. Berdasarkan data dari (Rikesdas) tahun 2013, prevalensi tumor/kanker di Indonesia adalah 1,4 per 1000 penduduk, atau sekitar 330.000 orang. Kanker tertinggi di Indonesia pada wanita adalah kanker payudara dan kanker leher rahim. Data menunjukkan bahwa pasien kanker payudara75\% melakukan kemoterapi. Hasil penelitian menemukan pasien dengan kemoterapi $>60 \%$ menyebabkan rambut rontok, kuku menghitam, mual muntah dan hilang nafsu makan. Tujuan penelitian ini untuk mengetahui faktor-faktor yang berhubungan dengan kepatuhan kemoterapi pada pasien kanker payudaradiruang rawat inap Thursina II BLUD RSU dr. Zainoel Abidin Banda Aceh Tahun 2017. Penelitian ini dilakukan pada tanggal 01 April s/d 30 Mei 2017. Jenis penelitian ini berbentuk korelasi dengan pendekatan cross sectional study. Populasi penelitian ini adalah seluruh pasien kanker payudarayang menjalani kemoterapi. Pengambilan sampel dalam penelitian ini adalah secara Accidental Sampling yang berjumlah 65 responden. Data dianalisis dengan menggunakan uji Chi Square. Hasil yang didapat adalah ada hubungan antara konsep diri dengan kepatuhan kemoterapi ( $p$-value=0,013), ada hubungan antara biaya dengan kepatuhan kemoterapi ( $p$-value $=0,036$ ), ada hubungan antara dukungan keluarga dan kerabat dengan kepatuhan kometerapi ( $p$-value $=0,002)$, ada hubungan antara efek samping kemoterapi dengan kepatuhan kemoterapi ( $p$-value $=0,007)$. Diharapkan kepada petugas dilingkungan ruang rawat inap BLUD RSU dr. Zainoel Abidin Banda Aceh, agar dapat meningkatkan asuhan keperawatan dan menjalankan standar operasional prosedur terhadap tindakan kemoterapi khususnya bagi pasien kanker payudara.
\end{abstract}

Kata kunci: Kepatuhan, Kemoterapi, Kanker payudara

Kanker payudara merupakan penyebab utama dalam hal insiden dan kematian yang terjadi akibat kanker pada wanita (Tjindarbumi, 2004). Diperkirakan pada tahun 2030 insidens kanker dapat mencapai 26 juta orang dan 17 juta diantaranya meninggal akibat kanker, terlebih untuk negara miskin dan berkembang kejadiannya akan lebih cepat (WHO, 2013). Prevalensi kejadian kanker payudara di dunia kurang lebih sekitar $16 \%$ dari semua kasus kanker pada wanita. Problem kanker payudara di Indonesia menjadi lebih besar karena di atas $70 \%$ pasien datang ke dokter pada stadium yang sudah lanjut (Pramitasari, 2008).

Saat ini kanker payudara pada wanita merupakan masalah kesehatan utama bagi masyarakat di seluruh dunia. Kanker jenis ini adalah salah satu kanker yang paling umum terjadi 
di kalangan wanita, baik pada negara maju maupun negara berkembang. Satu dari sepuluh semua kasus kanker yang terjadi di seluruh dunia setiap tahun adalah kanker payudara (Ferlay dalam Pertiwi, 2012).

Berdasarkan data Riset Kesehatan Dasar (Rikesdas) tahun 2013 dalam Kemenkes (2014), prevalensi tumor/kanker di Indonesia adalah 1,4 per 1000 penduduk, atau sekitar 330.000 orang. Kanker tertinggi di Indonesia pada perempuan adalah kanker payudara dan kanker leher rahim.

Menurut Persatuan Ahli Bedah Onkologi Indonesia (2005) penatalaksanaan/pengobatan utama penyakit kanker meliputi 4 macam yaitu pembedahan, radioterapi, kemoterapi dan hormoterapi. Pembedahan dilakukan untuk mengambil massa kanker dan memperbaiki komplikasi yang mungkin terjadi. Sementara tindakan radioterapi dilakukan dengan sinar ionisasi untuk menghancurkan kanker. Kemoterapi dilakukan untuk membunuh sel kanker dengan obat anti-kanker (sitostatika). Sedangkan hormoterapi dilakukan untuk mengubah lingkungan hidup kanker sehingga pertumbuhan sel-selnya terganggu dan akhirnya mati sendiri.

Deteksi dini kanker payudara dapat menekan angka kematian sebesar 25\%-30\%. Pemeriksaan sendiri (Sadari) sangat penting dianjurkan kepada masyarakat khususnya wanita karena hampir $86 \%$ benjolan dipayudara ditemukan oleh penderita sendiri (Pramitasari, 2008).

Selain pemeriksaan dengan cara Sadari, ada juga yang disebut dengan Sadanis (periksa payudara klinis) yaitu pemeriksaan klinis di mulai dengan mewawancarai penderita kanker payudara, pemeriksaan klinis payudara, untuk mencari benjolan atau kelainan lainnya, infeksi payudara, palpasi, dan pemeriksaan kelenjar getah bening regional atau aksila. Dilanjutkan dengan pemeriksaan penunjang dilakukan dengan menggunakan alat-alat tertentu antara lain dengan, ultrasonografi, scintimmografi, dan pemeriksaan histopatologi untuk mendiagnosis secara pasti penderita kanker payudara (Smeltzer \& Bare, 2010).

Kemampuan masyarakat melakukan pemeriksaan payudara sendiri (Sadari) dan pemeriksaan payudara klinis (Sadanis) sangat rendah. Hal ini menimbulkan masalah tidak terdeteksinya kanker payudara secara dini. Hampir $75 \%$ penderita penyakit kanker payudaradatang sudah stadium lanjut.

Perkembangan terapi banyak dilakukan untuk meningkatkan survival dan prognosis pasien kanker payudara. Variasi pilihan terapi kanker payudara diberikan dengan mempertimbangkan banyak faktor, meliputi usia, status menopausal, komorbid, stadium kanker, faktor biologis dan riwayat kemoterapi (Chan dan Yeo, 2011).

Salah satu terapi yang diberikan pada pasien kanker payudara yaitu tindakan kemoterapi. Kemoterapi adalah proses pemberian obat-obatan anti kanker dalam bentuk cair atau kapsul atau melalui infus yang bertujuan membunuh sel kanker, namun tidak hanya sel kanker yang terbunuh, tetapi juga sel-sel sehat yang ada di seluruh tubuh juga terbunuh (Kartikawati, 2013). Data menunjukkan bahwa pasien kanker payudara 75\% adalah dilakukan terapi kemoterapi. Hasil penelitian menyebutkan bahwa pasien kanker payudara dengan kemoterapi $>60 \%$ menjalani kemoterapi dengan berbagai keluhan seperti rambut rontok, kuku menghitam, mual muntah dan hilang nafsu makan.

Menurut Haynes (dalam Bosworth dkk, 2008) mendefinisikan kepatuhan pasien sebagai sejauh mana perilaku seorang pasien dalam melaksanakan proses pengobatan; melaksanakan diet; memodifikasi perilaku; atau berkonsultasi di klinik, adalah sesuai dengan anjuran dan rekomendasi medis. Kepatuhan pasien dalam berobat dapat pula diketahui melalui sejauh mana pasien tersebut setuju dengan saran-saran medis yang diberikan dalam hal melaksanakan terapi, mengubah gaya hidup, dan mematuhi jadwal konsultasi medis (Marque dan Pierin, 2007).

Hasil penelitian Hastuty (2015), tentang Hubungan tingkat pengetahuan $\mathrm{Ca}$ Mammae dengan motivasi pasien mengikuti kemoterapi di Ruang One Day Care RSUD dr. Moewardi Surakarta. Pada 84 responden menemukan responden yang mengikuti kemoterapi mempunyai tingkat pengetahuan $\mathrm{Ca}$ Mammae baik sebanyak 41 orang $(48,8 \%)$, mempunyai motivasi baik yaitu sebanyak 41 orang $(48,8 \%)$, demikian juga korelasi hubungan yang signifikan antara tingkat pengetahuan tentang Ca Mammae dengan motivasi pasien melakukan kemoterapi (p-value 0,001).

BLUD RSU dr. Zainoel Abidin Banda Aceh merupakan salah satu Rumah Sakit rujukan tertinggi di provinsi Aceh yang melaksanakan pelayanan kemoterapi pada pasien kanker, bahkan terdapat ruang khusus yang mengelola pelayanan kemoterapi yaitu ruang Thursina II dan telah memiliki konsultan Onkologi baik dari bagian penyakit dalam, bagian bedah, dan bagian kebidanan (Data Kepegawaian RSUDZA, 2016).

Berdasarkan data awal di ruang rawat inap Thursina II BLUD RSU Dr.Zainoel Abidin Banda Aceh jumlah pasien kanker payudara periode 
Juli-Desember 2016 terdapat 184 pasien (Medical Record RSUDZA 2016). Hasil wawancara singkat dengan pada tanggal 22 Desember 2016 terhadap 6 orang pasien yang menjalani kemoterapi, terungkap bahwa 4 orang $(66,67 \%)$ kemoterapi tidak sesuai jadwal (tidak patuh) karena takut dan 2 orang $(33,33 \%)$ pasien pasien datang kemoterapi sesuai jadwal (patuh) karena dukungan keluarga.

Berdasarkan uraian di atas, maka peneliti tertarik untuk meneliti tentang "Faktor-faktor apa sajakah yang berhubungan dengan kepatuhan kemoterapi pada pasien kanker payudara di BLUD RSU dr. Zainoel Abidin Banda Aceh 2017”.

Penelitian ini bertujuan untuk mengetahui Faktor-faktor apa sajakah yang berhubungan dengan kepatuhan kemoterapi pada pasien kanker payudara di BLUD RSU dr. Zainoel Abidin Banda Aceh tahun 2017. Adapun manfaat penelitian ini antara lain yaitu: 1) Sebagai bahan masukan bagi institusi kesehatan khususnya RSUD dr Zainoel Abidin Banda Aceh, untuk meningkatkan pelayanan kesehatan, terutama dalam upaya promotif dan preventif melalui program pendidikan kesehatan. 2) Sebagai bahan masukan dalam menyusun SOP (Standar Operasional Prosedur) oleh perawat kepada pasien yang ada terapi kemoterapi pada pasienkanker payudara.3) Sebagai bahan masukan bagi peneliti lain yang ingin meneliti tentang terapi kemoterapi 4) Sebagai informasi tambahan agar pasien mengetahui terapi kemoterapi dan bersedia menjalani tindakan kemoterapi secara berkala sesuai dengan jadwal yang telah ditetapkan.

\section{METODE}

Jenis penelitian ini adalah berbentuk korelasi dengantujuan untuk mengetahui faktor-faktor apa sajakah yang berhubungan dengan kepatuhan kemoterapi pada pasien kanker payudara di BLUD RSU dr. Zainoel Abidin Banda Aceh.Desain penelitian ini menggunakan Cross Sectional Study yaitu suatu variabel sebab atau resiko dan akibatatau kasus yang terjadi pada objek penelitian dimana diukur atau dikumpulkan secara simultan.Populasi dalam penelitian ini adalah seluruh pasien kanker payudara yang dilakukan tindakan kemoterapi diruang Thursina II BLUD RSU dr. Zainoel Abidin Banda Aceh berjumlah sebanyak 184 orang (Data dari register ruang Thursina Juli-Desember 2016). Sampel adalah pasien kanker payudara yang datang melakukan kemoterapi.Teknik pengambilan sampel yang digunakan adalah Accidental sampling (yang kebetulan ada pada saat pengumpulan data) yang berjumlah 65 orang. Tempat penelitian ini telah dilakukan diruang rawat inap Thursina II BLUD RSU dr. Zainoel Abidin Banda Aceh pada tanggal 01 April s/d 30 Mei 2016. Alat pengumpulan data menggunakan kuesioner yang di kembangkan oleh peneliti berdasarkan konsep dan telah dilakukan uji kuesioner. Analisis data dilakukan untuk mengukur variabel, konsep diri, biaya, dukungan keluarga/kerabat dan efek samping kemoterapi pada pasien kanker payudara (Stuart \& Sundeen, 2002 dan Smeltzer, \& Bare, 2010) menggunakan uji statistik Chi-Square.

\section{HASIL}

\section{A. DATA DEMOGRAFI RESPONDEN}

Tabel 1. Distribusi Data Demografi Responden

\begin{tabular}{lrr}
\hline \multicolumn{1}{c}{ Kategori } & f & \multicolumn{1}{c}{$\%$} \\
\hline Umur (kelompok usia & & \\
resti) & 0 & 0,00 \\
<20 tahun & 3 & 4,6 \\
20-35 tahun & 62 & 95,4 \\
$>35$ tahun & & \\
\hline Pendidikan & & \\
Dasar & 14 & 21,5 \\
Menengah & 32 & 49,2 \\
Tinggi & 19 & 29,3 \\
\hline Jumlah kemoterapi & & \\
Satu kali & 8 & 12,3 \\
Lebih dari satu kali & 57 & 87,7 \\
\hline Total & 65 & 100 \\
\hline
\end{tabular}

Data demografi responden terdiri dari umur yang merupakan kelompok usia resti, pendidikan dan jumlah kemoterapi. Berdasarkan analisis data demografi ditinjau dari aspek umur distribusi tertinggi umur responden dalam penelitian ini adalah kategori usia $>35$ tahun sebanyak 62 orang $(95,4 \%)$, aspek tingkat pendidikan kategori menengah 32 orang $(49,2 \%)$ dan ditinjau dari aspek jumlah menjalani kemoterapi paling banyak kategori lebih dari satu kali sebanyak 57 orang $(87,7 \%)$. 


\section{B. ANALISIS UNIVARIAT}

Tabel 2. Distribusi Frekuensi Konsep Diri, Biaya, Dukungan Keluarga/Kerabat dan Efek Samping Kemoterapi

\begin{tabular}{lcc}
\hline \multicolumn{1}{c}{ Variabel } & f & \% \\
\hline Konsep Diri & & \\
Baik & 49 & 75,4 \\
Kurang & 16 & 24,6 \\
\hline Biaya & & \\
Baik & 36 & 55,4 \\
Kurang & 29 & 44,6 \\
\hline Dukungan & & \\
Keluarga/kerabat & & \\
Baik & 36 & 55,4 \\
Kurang & 29 & 44,6 \\
\hline Efek Samping & & \\
Kemoterapi & & \\
Baik & 24 & 36,9 \\
Kurang & 41 & 63,1 \\
\hline
\end{tabular}

Berdasarkan tabel 2 didapatkan distribusi tertinggi konsep diri responden adalah kategori baik sebanyak 49 responden $(75,4 \%)$. Distribusi biaya terbanyak berada pada kategori baik yaitu 36 responden $(55,4 \%)$. Selanjutnya distribusi tertinggi dukungan keluarga/kerabat adalah kategori baik sebanyak 36 responden $(55,4 \%)$ dan untuk distribusi efek samping kemoterapi responden terbanyak adalah kategori kurang berjumlah 41 responden $(63,1 \%)$.

\section{ANALISIS BIVARIAT}

Tabel 3. Hubungan Konsep Diri dengan Kepatuhan Kemoterapi

\begin{tabular}{|c|c|c|c|c|c|c|c|}
\hline \multirow{3}{*}{$\begin{array}{l}\text { Konsep } \\
\text { Diri } \\
\end{array}$} & \multicolumn{4}{|c|}{ Kepatuhan } & \multirow{2}{*}{\multicolumn{2}{|c|}{ Total }} & \multirow{3}{*}{$a$} \\
\hline & \multicolumn{2}{|c|}{ Baik } & \multicolumn{2}{|c|}{ Kurang } & & & \\
\hline & $f$ & $\%$ & f & $\%$ & f & $\%$ & \\
\hline Baik & 37 & 75,5 & 12 & 24,5 & 49 & 100 & \\
\hline Kurang & 6 & 37,5 & 10 & 62,5 & 16 & 100 & 0,05 \\
\hline Jumlah & 43 & 66,2 & 22 & 33,8 & 65 & 100 & \\
\hline$p$-value & 0.0 & & & & & & \\
\hline
\end{tabular}

Berdasarkan tabel 3 diketahui bahwa dari 65 responden konsep diri kategori baik sebanyak 49 responden, tingkat kepatuhan adalah kategori baik yaitu 37 responden $(75,5 \%)$ sedangkan dari 16 responden konsep diri yang kurang, ternyata tingkat kepatuhan adalah kategori kurang yaitu 10 responden $(62,5 \%)$. Hasil uji statistik dengan $C h i$ Square dengan tingkat kemaknaan probabilitas nilai $a=5 \% \quad(0,05)$ didapatkan nilai $p$-value $0,013<0,05$ sehingga dapat dijelaskankan bahwa Ho ditolak, berarti ada hubungan bermakna antara konsep diri dengan kepatuhan kemoterapi pada pasien kanker payudara.
Tabel 4. Hubungan Biaya dengan Kepatuhan Kemoterapi

\begin{tabular}{lcccccccc}
\hline \multirow{2}{*}{ Biaya } & \multicolumn{4}{c}{ Kepatuhan } & \multicolumn{2}{c}{ Total } & \multirow{2}{*}{$\boldsymbol{a}$} \\
\cline { 2 - 6 } & \multicolumn{2}{c}{ Baik } & \multicolumn{1}{c}{ Kurang } & & & \\
\hline & f & \% & \multicolumn{1}{c}{ f } & \% & f & \% & \\
\hline Baik & 28 & 77,8 & 8 & 22,2 & 36 & 100 & \multirow{2}{*}{0,05} \\
Kurang & 15 & 51,7 & 14 & 48,3 & 29 & 100 & \\
\hline Jumlah & 43 & 66,2 & 22 & 33,8 & 65 & 100 & \\
\hline p-value & 0,036 & & & & & \\
\hline
\end{tabular}

Berdasarkan tabel 4 diketahui bahwa dari 65 responden, mempunyai kategori biaya dalam keadaan baik sebanyak 36 responden mempunyai tingkat kepatuhan baik terhadap kemoterapi sebanyak 28 responden $(77,8 \%)$ sedangkan dari29responden yang mempunyai biaya kurang, ternyata tingkat kepatuhan adalah kategori kurang yaitu 14 responden $(48,3 \%)$. Hasil uji statistik dengan Chi Square dengan tingkat kemaknaan probabilitas nilai $a=5 \%(0,05)$ didapatkan nilai $p$-value $0,036<0,05$ sehingga dapat di jelaskan Ho ditolak, berarti ada hubungan bermakna antara biaya dengan kepatuhan kemoterapi pada pasien kanker payudara.

\begin{tabular}{|c|c|c|c|c|c|c|c|}
\hline \multicolumn{3}{|c|}{$\begin{array}{l}\text { Tabel 5. Hubungan } \\
\text { Kerabat } \\
\text { Kemoterapi }\end{array}$} & \multicolumn{2}{|c|}{$\begin{array}{l}\text { Dukungan } \\
\text { dengan }\end{array}$} & \multicolumn{3}{|c|}{$\begin{array}{r}\text { Keluarga/ } \\
\text { Kepatuhan }\end{array}$} \\
\hline \multirow{3}{*}{$\begin{array}{l}\text { Dukungan } \\
\text { Keluarga/ } \\
\text { Kerabat }\end{array}$} & \multicolumn{4}{|c|}{ Kepatuhan } & \multirow{2}{*}{\multicolumn{2}{|c|}{ Total }} & \multirow{3}{*}{$a$} \\
\hline & \multicolumn{2}{|c|}{ Baik } & \multicolumn{2}{|c|}{ Kurang } & & & \\
\hline & f & $\%$ & f & $\%$ & f & $\%$ & \\
\hline Baik & 30 & 83,3 & 6 & 16,7 & 36 & 100 & \\
\hline Kurang & 13 & 44,8 & 16 & 55,2 & 29 & 100 & 0,05 \\
\hline Jumlah & 43 & 66,2 & 22 & 33,8 & 65 & 100 & \\
\hline p-value & \multicolumn{4}{|c|}{0,002} & & & \\
\hline
\end{tabular}

Hasil pada tabel 5 diketahui bahwa dari 65 responden dukungan keluarga/kerabat 36 responden pada kategori baik, mempunyai kepatuhan adalah kategori baik yaitu 30 responden $(83,3 \%)$, sedangkan dari 29 responden dukungan keluarga/kerabat yang kurang, ternyata tingkat kepatuhan pada kategori kurang 16 responden $(55,2 \%)$. Hasil uji statistik dengan Chi Square dengan tingkat kemaknaan probabilitas nilai $a=5 \%(0,05)$ didapatkan nilai $p$-value 0,002 , dengan demikian dapat dijelaskan bahwa Ho ditolak, berarti ada hubungan bermakna antara dukungan keluarga dan kerabat dengan kepatuhan kemoterapi pada pasien kanker payudara. 
Tabel 6. Hubungan Efek Samping Kemoterapi dengan Kepatuhan Kemoterapi

\begin{tabular}{|c|c|c|c|c|c|c|c|}
\hline \multirow{3}{*}{$\begin{array}{c}\text { Efek } \\
\text { Samping } \\
\text { Kemo- } \\
\text { terapi } \\
\end{array}$} & \multicolumn{4}{|c|}{ Kepatuhan } & \multirow{2}{*}{\multicolumn{2}{|c|}{ Total }} & \multirow{3}{*}{$a$} \\
\hline & \multicolumn{2}{|c|}{ Baik } & \multicolumn{2}{|c|}{ Kurang } & & & \\
\hline & f & $\%$ & f & $\%$ & f & $\%$ & \\
\hline Baik & 21 & 87,5 & 3 & 12,5 & 24 & 100 & \\
\hline Kurang & 22 & 53,7 & 19 & 46,3 & 41 & 100 & J \\
\hline Jumlah & 43 & 66,2 & 22 & 33,8 & 65 & 100 & \\
\hline$p$-value & 0,0 & & & & & & \\
\hline
\end{tabular}

Berdasarkan analisis data pada tabel 6 diketahui bahwa dari 65 responden pengetahuan tentang efek samping kemoterapi 24 responden kategori baik, ternyata tingkat kepatuhan pada kategori baik yaitu 21 responden $(87,5 \%)$ sedangkan dari 41 responden efek samping tindakan kemoterapi yang kurang, ternyata tingkat kepatuhan kemotearpi kategori kurang yaitu 19 responden (46,3\%). Hasil uji statistik dengan Chi Square dengan tingkat kemaknaan probabilitas nilai $a=5 \%(0,05)$ didapatkan nilai p-value $0,007<0,05$ dengan demikian dapat di jelaskankan bahwa Ho ditolak, berarti ada hubungan bermakna antara efek samping kemoterapi dengan kepatuhan kemoterapi pada pasien kanker payudara.

\section{PEMBAHASAN}

\section{Hubungan Konsep Diri dengan Kepatuhan Kemoterapi}

Konsep diri merupakan ide, pikiran, kepercayaan dan pendirian yang diketahui individu tentang dirinya dan mempengaruhi individu dalam berhubungan dengan orang lain(Stuart \& Sundeen, 2002). Konsep diri (self-concept) bagian dari masalah kebutuhan psikososial yang tidak didapat sejak lahir, akan tetapi dapat dipelajari sebagai hasil dari pengalaman seseorang terhadap dirinya (Alimul (2006). Hal ini dikarenakan sebagian besar pasien kanker payu dara mengalami konsep diri negatif $(87.9 \%)$ dan hanya sebagian kecil pasien tersebut yang mengalami konsep diri positif (12.1\%) (Hartati, 2008).

Konsep diri memberikan arah dan kerangka acuan kepada pasien, hal ini mempengaruhi manajemen diri terhadap situasi dalam berinteraksi danberhubungan dengan orang lain terutama petugas kesehatan, keluarga dan kerabatnya. Ketidaksesuaian antara aspek tertentu dari dan persepsi tentang kesehatan sangat berkaitan erat dengan satu sama lain. Pasien yang mempunyai keyakinan tentang kesehatan yang baik akan dapat meningkat konsep diri (Perry \& Potter, 2005).

Individu yang mempunyai konsep diri baik semasa sehat akan melakukan berbagai pemeriksaan kesehatan (medical check up) untuk berbagai fungsi organ tubuhnya, termasuk payudara. Di United Kingdom, tingkat diagnosis kanker adalah 91\%, Data ini telah dieksplorasi untuk melihat variasi di unit praktikdan menunjukkan variasi yang cukup luas dalam penggunaan alat untuk diagnosis seperti mamografi (26-100\%), ultrasound (4-96\%), dan biopsi jarum (6-57\%). Meskipun hal ini tidak secara jelas mengubah stadium diagnosis kanker pada individu (Monypenny, 2006).

Pada penelitian ini diketahui bahwa ada hubungan bermakna antara konsep diri dengan kepatuhan kemoterapi pada pasien kanker payudara. Hal ini sesuai dengan penelitian yang dilakukan oleh Hartati, (2008) tentang Konsep diri dan kecemasan wanita penderita kanker payudara di poli Bedah Onkologi RSU pusat Haji Adam Malik Medan". Hasil penelitian menunjukkan bahwa sebagian besar wanita penderita kanker payudara memiliki konsep diri negatif $(87,9 \%)$, dan yang memiliki konsep diri positif hanya sebagian kecil (12,1\%). Mayoritas wanita penderita kanker payudara mengalami kecemasan sedang $(42,4 \%)$, dan sebagian lagi mereka menujukkan kecemasan berat $(30,3 \%)$, serta kecemasan ringan $(27,3 \%)$.

Hasil penelitian dari Bandiyah (2015) dengan judul "Hubungan gambaran diri dengan kepatuhan menjalani kemoterapi pada pasien kanker payudara di RSUD Kraton Pekalongan", hasil uji statistik diketahui ada hubungan bermakna antara gambaran diri dengan kepatuhan menjalani kemoterapi pada pasien kanker payudara ( $p$-value 0,000$)$.

Pihak Rumah Sakit sebaiknya menjadikan sebagai masukan informasi tentang pemberian asuhan keperawatan pasien kanker payudara dengan kemoterapi agar memperhatikan aspek psikologis pasien sehingga dapat meningkatkan gambaran diri pasien. Hal ini dikarenakan gambaran diri dapat dipengaruhi oleh efek kemoterapi terutama fisiknya seperti rambut rontok, mual, muntah dan lemah. Pasien dengan kanker payudara mengalami konsep diri kurang baik dan merasa tidak adekuat sebagai ibu dan istri. Perempuan yang berperan sebagai ibu dan istri dalam keluarga yang mengalami kanker payudara merasa konsep dirinya tidak utuh sebagai seorang ibu atau perempuan dibandingkan dengan perempuan dengan kondisi sehat.

Konsep diri pasien pada hasil penelitian berada pada kategori baik, namun jika ada kerabat, 
saudara yang berkunjung pasien dengan perasaaan malu dan menutupi keadaaan penyakitnya kepada mereka. Tindakan perawatan luka, kadangkala pasien meminta perawat merahasiakan tentang kondisi payudaranya dan tindakan efek samping kemoterapi seperti rambut rontok, kulit menghitam dan berkeriput. Efek samping kemoterapi tersebut menyebabkan konsep diri pasien sebagian menjadi kurang baik.

Hasil penelitian ini menunjukkan bahwa dari 65 responden mempunyai konsep diri kategori baik berjumlah 49 orang $(75,4 \%)$. Keadaan ini bila kita kaitkan dengan faktor usiaresponden sebagian pada kategori usia >35 tahun (95.4\%) dan tergolong kelompok resiko tinggi karena ada beberapa orang responden sudah menikah belum ada anak dan melahirkan anak pertama diatas usia $>35$ tahun. Kondisi ini merupakan faktor yang memudahkan dalam menjelaskan tujuan kemoterapi dengan harapan pasien patuh kemotearpi selanjutnya (sesuai jadwal), namun disilain mereka adalah kelompok resti dan menglami kanker payudara sehinggan penjelasan tentang kepatuhan kemoterapi tersebut membutuhkan waktu yang lama karena sebagian besar responden kurang fokus karena takut efek samping kemoterapi dan mereka tidak sanggup menahan keluhan tersebut.

\section{Hubungan Biaya dengan Kepatuhan Kemoterapi}

Hasil penelitian ini didapatkan bahwa faktor biaya dengan kepatuhan kemoterapi ada hubungan bermakna antara biaya dengan kepatuhan kemoterapi pada pasien kanker payudara. Hasil penelitian ini sesuai dengan teori dimana biaya atau harga dari kemoterapi relatif mahal, biasanya pasien kanker seringkali tidak patuh terhadap pengobatan dengan berbagai alasan, seperti masalah biaya dan ingin mencoba pengobatan alternatif (Samuel, 2011).

Hasil penelitian ini sesuai dengan pendapat Wirawan (2008), bahwa biaya adalah sejumlah uang yang harus dibayarkan kepada pihak pelayanan kesehatan yang selaras dengan pelayanan yang diterima oleh pasien seperti biaya tenaga kesehatan, obat-obatan. Masyarakat dengan ekonomi rendah tidak mampu untuk menerima beban biaya pelayanan yang lebih tinggi sehingga memilih pelayanan kesehatan yang biayanya dapat dijangkau.

Pasien kanker payu dara yang terdata pada dokter pribadi di Association of Breast Surgery UK berjumlah 16.407 pasien pada tahun 2002 . Proporsi pasien tidak menerima operasi meningkat dari $6 \%$ pada mereka yang berusia
50-64 sampai $41 \%$ pada usia 80 tahun ke atas. Secara keseluruhan, $48 \%$ dilakukan pembedahan. Proporsi pasien yang diobati Radioterapi dan kemoterapi turun tajam seiring bertambahnya usia, sedangkan proporsi yang diobati dengan terapi hormon meningkat seiring bertambahnya usia (Lagord et.al, 2006).

Hasil penelitian lain oleh Hermawan (2011), tentang Analisis faktor-faktor yang berhubungan dengan masyarakat berobat di Puskesmas Kecamatan Buayan kabupaten Kebumen. Hasil penelitian menunjukkan, ada hubungan yang bermakna antara pelayanan kesehatan p-value $(0,030)$, faktor biaya pelayanan $p$-value $(0,002)$, pengalaman pemulihan $p$-value $(0,027)$, faktor motivasi $p$-value $(0,000)$, faktor jarak $p$-value $(0,022)$.

Peneliti berasumsi bahwa biaya pelayanan kesehatan saat ini makin tinggi, sangat mempengaruhi pasien memilih kemoterapi. Kemoterapi di BLUD RSU Dr Zainoel Abidin, khususnya bagi pasien kanker payudara, sudah ada asurasnsi dari pemerintah seperti BPJS, JKA (Jaminan kesehatan Aceh) dan asuransi lainnya yang sudah dibiayai pemerintah adalah pasien rujukan. Saat wawancara sebagian responden memerlukan biaya akomodasi selama perawatan dari kabupaten kota dan kebutuhan keluarga selama perjalanan dan biaya pengobatan dalam jangka waktu lama juga menjadi hal utama terkait kepatuhan kemoterapi.

Hasil penelitian ini menunjukkan frekwensi pasien melakukan Kemoterapi $>1$ kali sebanyak 57 orang $(87.7 \%)$, namun, skedulnya melewati jadwal yang telah di tentukan 1-3 hari.Hasil wawancara dengan beberapa responden, kondisi ini di sebabkan biaya yang di punyai oleh keluarga belum cukup untuk biaya akomodasi seperti transport, akomodasi untuk 1-2 orang anggota keluarga yang mendampingi selama kemoterapi di Banda Aceh.

Pasien yang menggunakan fasilitas asuransi di Rumah Sakit, tidak dikenakan lagi pembiayaan apapun, namun jarak tempat tinggal pasien di daerah ke Rumah Sakit yang membutuhan biaya, hal inilah pasien terkadang kurang patuh atau menunda jadwal kemoterapi yang telah di rencanakan tim medis. Faktor ini juga yang menyebabkan pasien masuk ke stadium lanjut/ penyakit sudah bermetastasis dan komplikasi ke organ lainnya.

\section{Hubungan Dukungan Keluarga dan Kerabat dengan Kepatuhan Kemoterapi}

Dukungan keluarga dan kerabat pada penelitian ini, ada hubungan bermakna antara 
dukungan keluarga dan kerabat dengan kepatuhan kemoterapi. Hal ini menunjukkan bahwa pasien kanker payudara yang ada dukungan keluarga dan kerabat dalam kategori baik, maka patuh menjalankan kemoterapi, sedangkan pasien kanker payudara yang dukungan keluarga dan kerabat kurang baik maka kurang patuh dalam menjalankan kemoterapi.

Hasil penelitian ini sesuai dengan teori dimana Setiap orang memberikan reaksi yang berbeda ketika pertama kali mendengar mereka mengidap kanker. Perasaan akan menjadi kacau dan mudah berubah. Perasaan khawatir dan tertekan merupakan reaksi yang normal. Beberapa orang cenderung memikirkan penyakit saja sementara yang lain akan lebih berfikir tentang pengobatannya. Keluarga dan teman seringkali sangat dibutuhkan sebagai pendamping atau teman dalam menghadapi masa sulit tersebut (Stuart \& Sundeen, 2002). Berbicara dengan keluarga dan teman dapat meringankan masalah yang dihadapi. Hasil analisis statistik menunjukkan bahwa tidak ada hubungan antara istilah diagnosis $p$-value $=0,289$ dan stadium penyakit $p$-value $=0,354$ dengan tingkat depresi, namun terdapat hubungan hubungan antara terapi dengan tingkat depresi $p$-value $=0,001$ pada kanker payudara (Suharmilah, 2013).

Dukungan keluarga merupakan sikap, tindakan dan penerimaan keluarga terhadap anggotanya. Anggota keluarga dipandang sebagai bagian yang tidak terpisahkan dalam lingkungan keluarga. Anggota keluarga memandang bahwa orang yang bersifat mendukung selalu siap memberikan pertolongan dan bantuan jika diperluakan (Friedman, 2010).

Hal ini sesuai dengan penelitian yang dilakukan oleh Sari (2011) tentang Hubungan dukungan keluarga terhadap motivasi pasien kanker payudara dalam menjalani kemoterapi diruang Cendrawasih 1 RSUD Arifin Achmad Riau. Hasilnya dukungan keluarga rendah memiliki motivasi yang rendah sebanyak 10 orang $(66,7 \%)$, sedangkan yang memiliki dukungan tinggi memiliki motivasi tinggi sebanyak 5 orang $(33,3 \%)$. Responden dengan dukungan keluarga tinggi memiliki motivasi rendah sebanyak 4 orang $(18,2 \%)$, sedangkan yang memiliki motivasi tinggi sebanyak 18 orang $(81,8 \%)$. Hasil penelitian menjelaskan ada hubungan yang signifikan antara dukungan keluarga terhadap motivasi pasien kanker payudara dalam menjalani kemoterapi ( $p$-value 0,008).

Kemudian penelitian yang dilakukan oleh Ocktaviani (2015) dengan judul Hubungan dukungan keluarga dengan pelaksanaan kemoterapi pada pasien ca mamae di RSUD
Panembahan Senopati Bantul Yogyakarta dengan hasil uji analisis Chi Square didapatkan nilai $0,000(<0,05)$ dan koefisien korelasi sebesar 0,707 sehingga dinyatakan ada hubungan bermakna dan keeratan hubungan kuat. Sebagian besar responden mendapatkan dukungan keluarga dengan kategori tinggi yaitu 24 orang (24\%), dan pelaksanaan kemoterapi sebagian besar dalam kategori patuh yaitu 31 orang $(93,3 \%)$.

Penulis berasumsi, dukungan keluarga dan kerabat sangat dibutuhkan pasien yang mengalami kanker payudara yang menjalani kemoterapi, hal ini dikarenakan dukungan keluarga dan kerabat merupakan salah satu motivasi yang paling baik bagi bagi pasien yang menjalani kemoterapi.Terbukti pasien tidak ada yang dating sendiri saat kemoterapi, Sehingga pasien lebih menunggu keluarga dalam menjalankan kemoterapi dan hal ini dapat dikaitkan dengan hasil penelitian jumlah responden 57 orang (87.7\%) melakukan kunjungan ulang kemoterapi lebih dari satu kali dan 100\% didampingi keluarga saat dilakukan kemoterapi. Hal ini menunjukkan dukungan keluarga pada pasien sangat baik, sehingga pasien termotivasi utuk mau menjalankan kemoterapi walaupun skedulnya berubah 1-3 hari dari jadwal.

\section{Hubungan Efek Samping Kemoterapi dengan Kepatuhan Kemoterapi}

Efek samping kemoterapi dengan kepatuhan kemoterapi ditemukan ada hubungan bermakna antara efek samping kemoterapi dengan kepatuhan kemoterapi pada pasien kanker payudara. Hasil penelitian sesuai dengan teori dimana Kemoterapi menyebabkan melosupresi dan beresiko menimbulkan infeksi dan perdarahan. Kerusakan membrane mukosa menyebabkan gangguan pencernaan. Mual dan muntah merupakan efek samping yang sangat ditakutkan oleh pasien pada waktu akan menjalani kemoterapi. Semua jaringan yang membelah dengan cepat seperti folikel rambut (alopesia) dan epitel saluran germinal (infertilitas) sangat rentan terhadap efek kemoterapi. Kehilangan rambut akibat pemberian kemoterapi adalah sesuatu yang sangat ditakutkan oleh pasien dan pasien selalu bertanya kapan terjadinya, apakah akan tumbuh lagi, apakah tumbuhnya lebih tipis, dan bagaimana dengan rambut daerah lainnya (Ramli, 2010).

Efek samping lain adalah adanya kekambuhan lokal sering dikaitkan dengan kejadian selanjutnya dan metastasis yang lebih jauh. Pengobatan sistemik profilaksis secara teoritis dibenarkan, namun dampaknya terhadap 
prognosis tidak jelas. Perawat dalam konteks ini hanya melakukukan perawatan untuk meminimalkan efek komplikasi dengan perawatan sesuai SOP yang telah ditetapkan oleh tim dan rumah sakit (Dunst, $2001 \&$ Smeltzer, 2010).

Lebeau et al (2011), dalam penelitiannya menjelaskan bahwa ketidakpatuhan pasien kanker payudara dikarenakan (mixed effect logistic regression). Hasil penelitian pada 926 wanita, ketidakpatuhan terhadap keputusan klinis untuk pengobatan dikaitkan denganusia pasien yang lebih tua (OR 2.1; 95\% CI: 1.3-3.6) dan daerah (OR 3.0; 95\% CI: 1.2-7.4). Tidak sesuai dengan keputusan klinis untuk radioterapi dikaitkan dengan keterlibatan kelenjar getah bening atau adanya invasi vaskular peritumoural (OR 1.5; 95\% CI: 1.01-2.3) dan ketidakpatuhan terhadap keseluruhan pengobatan (keputusan klinis untuk pengobatan + terapi prosedur) dikaitkan dengan adanya kelenjar getah bening positif (OR 2.0; 95\% CI: 1.2-3.3), grade III versus grade I (OR 2,9; 95\% CI: 1,4-6,2), dan satu area perawatan versus yang lain (OR 3,5; 95\% CI: 1.7-7.1). Akhirnya, heterogenitas kepatuhan pada keseluruhan urutan pengobatan diidentifikasi antara unit kanker lokal ( $p$-value $<0,05)$.

Rahmatul (2008), mengemukakan dalam penelitiannya dengan judul hubungan mekanisme koping dengan stres pada pasien kanker dalam mengatasi efek samping kemoterapi diruangan kemoterapi bedah wanita RSU dr. M. Djamil Padang, menunjukkan bahwa terdapat hubungan bermakna antara mekanisme koping dengan stres pada pasien kanker dalam mengatasi efek samping kemoterapi ( $p$-value 0,027). Kemudian hasil penelitian yang dilakukan oleh Indriyawati (2015) dengan judul Efek samping kemoterapi terhadap mekanisme koping pada pasien kanker payudara di RSI Sultan Agung Semarang, menujukkan bahwa terdapat hubungan yang signifikan antara efek samping kemoterapi terhadap mekanisme koping pada pasien kanker payudara ( $p$-value 0,001).

Pasien menggunakan berbagai cara untuk mengatasi kecemasan yang dihadapi, diantaranya menolak tindakan sebelum mendapat penjelasan tentang tindakan kemoterapi. Hal ini dapat dikaitkan dengan data demografi dimana renponden mempunyai pendidikan terbanyak SMU yaitu 42 responden $(49,2 \%)$. Hal ini menunjukkan pasien secara tidak langsung mengharapkan penjelasan yang mendetil tentang tindakan kemoterapi dari dokter sebelum mereka menjalankan terapi tersebut. Responden yang menjalankan kemoterapi menyebabkan efek samping seperti rambut rontok (alopesia), kuku menghitam, mual muntah dan hilang nafsu makan. Gejala tersebut timbul pada pasien tidak persis sama, hal ini terkait dengan ketahaanan fisik. Kondisi ini idelalnya harus dipahami dengan baik oleh setiap pasien sehingga tidak mengurangi kepatuhan kemoterapi.

\section{SIMPULAN}

Hasil penelitian menyimpulkan beberap hal yaitu ada hubungan antara konsep diri dengan kepatuhan kemoterapi pada pasien kanker payudara $p$-value $(0,013)$, ada hubungan antara biaya dengan kepatuhan kemoterapi pada pasien kanker payudara $p$-value $(0,036)$, ada hubungan antara dukungan keluarga dan kerabat dengan kepatuhan kemoterapi $p$-value $(0,002)$. Selain itu juga ditemukan hubungan antara efek samping kemoterapi dengan kepatuhan kemoterapi pada pasien kanker payudara diruang Thursina II BLUD RSU dr. Zainoel Abidin Banda Aceh p-value $(0,007)$.

\section{SARAN}

Diharapkan kepada petugas dilingkungan ruang rawat inap BLUD RSU dr. Zainoel Abidin Banda Aceh, agar dapat meningkatkan kualitas pelayanan kemoterapi dengan memperhatikan faktor- faktor konsep diri pasien, biaya, dukungan keluarga dan kerabat serta efeksamping kemoterapi. Hal ini dilakukan untuk meningkatkan kepatuhan pasien pada kemoterapi sesuai skedul yang telah diprogramkan tim medis. bagi pasien kanker payudara.

Bedah, Vol 1. Edisi ke -8. Jakarta: EGC. Bosworth, hayden B. 2008. Improving Patient Treatment Adherence, A Clinical's Guide. New York: Springer Science + Bussiness Media, LLC.

Chan, A., Low, X.H., Yap, K.Y., 2012. 
Assessment of the relationship between adherence with antiemetic drug therapy an control of nausea and vomitting in breast cancer patients receiving anthracycline-based chemotherapy. Journal of Managed Care Pharmacy, 18: 385-394.

Dunst. 2001. Prognosis and Treatment of Locally Recurrent Breast Cancer. BioMed Central Ltd, (Print ISSN 1465-5411; Online ISSN 1465-542X).

Friedman. 2010. Keperawatan Keluarga: Teori dan Praktik. Jakarta. Ed. 3. EGC.

Hartati, A S. 2008. Konsep Diri dan Kecemasan Wanita Penderita Kanker Payudara Di Poli Onkologi Rumah Sakit Umum Pusat Haji Adam Malik Medan. Skrpsi PSIK-FK USU.

Hastuti, L.D. 2015. Hubungan Tingkat Pengetahuan Pasien tentang Ca Mammae dengan Motivasi Pasien Mengikuti Kemoterapi di Ruang One Day Care RSUD. Dr Moewardi Surakarta. Skripsi PSIK Surakarta.

Hermawan, A. 2011. Analisis faktor - faktor yang berhubungan dengan masyarakat berobat di Puskesmas Kecamatan Buayan Kabupaten Kebumen. Jurnal Ilmiah Kesehatan Keperawatan, Volume 7, No. 2, Juni 2011 http://ejournal.stikesmuhgombong.ac.id

Indriyawati, S. 2015. Efek Samping Kemoterapi terhadap Mekanisme Koping pada Pasien Kanker Payudara di RSI Sultan Agung Semarang. Skripsi, Fakultas Keperawatan Universitas Muhammadiyah Semarang.

Kartikawati, E. 2013. Awas!!! Bahaya Kanker Payudara dan Kanker Serviks. Bandung: Buku Baru.

Kementerian Kesehatan Nasional. 2014. Laporan Nasional Riset Kesehatan Dasar. Jakarta: Pusat Penelitian Pengembangan Kesehatan.

Lagord, Kearins, Lawrence, Bishop, Monypenny, Bates. 2006. Breast Cancer Clinical Outcome Measures Project: national results from year 1. Breast Cancer Research 2006, 8 (Suppl 1): P68 (doi: 10.1186/bcr1483).

Lebeau et. al. 2011. Breast Cancer Care Compared with Clinical Guidelines: an Observational Study in France. $B M C$ Public Health. http://www.biomedcentral.com

Marque, Patricia Andrea Crippa \& Pierin, Angela Maria Geraldo. 2007. Factors That Affect Cancer Patient Complience to Oral Antineoplastic Therapy. Journal of Acta Paul Enferm, 21(2), 323-329.

Medical Record RSUDZA. 2016. Buku Register Ruang Thursina. Banda Aceh: Rumah Sakit
Umum Daerah dr. Zainoel Abidin Banda Aceh.

Monypenny. 2006. How are Symptomatic Services Run in The United Kingdom? Breast Cancer Research 2006, 8 (Suppl 1): P5 (doi: 10.1186/bcr1420).

Ocktaviani, N. 2015. Hubungan Dukungan Keluarga dengan Pelaksanaan Kemoterapi pada Pasien Ca Mammae di Ruang RSUD Panembahan Bantul Yogyakarta. Skripsi, PSIK Aisyiah Jogyakarta.

Perry \& Potter. 2005. Buku Ajar Fundamental Keperawatan - Konsep, Proses dan Praktik. Vol 1. Jakarta : EGC

Pertiwi, M. P., Karini, S. M., \& widya Agustin, R. 2012. Hubungan Antara Resiliency dan Pengetahuan Tentang Pengobatan Kanker Payudara dengan Kepatuhan Pasien di RSUD Dr. Moewardi Surakarta. Wacana, 4(7).

Pramitasari, R. D. 2008. Perawatan Payudara (Edisi kedua). Yogyakarta: Mitra Cendekia Press.

Rahmatul. 2008. Hubungan Mekanisme Koping dengan Stres pada Pasien Kanker dalam Mengatasi Efek Samping Kemoterapi di Ruangan Kemoterapi Bedah Wanita Rumah Sakit Umum dr. M. Djamil Padang. Tesis, Fakultas Kedokteran Universitas Andalas. http://repository.unand.ac.id/5658/

Ramli, S. 2010. Deteksi Dini Kanker. Jakarta: Fakultas Kedokteran Universitas Indonesia.

Nurpeni, R. K. 2014. Hubungan Dukungan Keluarga dengan Tingkat Kecemasan pada Pasien Kanker Payudara. Coping (Community of Publishing in Nursing). [S.1.], v. 2, n. 3, oct. 2014. ISSN 2303-1298.

Samuel. 2011. Dividen Policy and Bank Perfoemance in Ghana International. Journal of Ekonomics and Finance, 3 (4).

Sari, M. 2011. Hubungan Dukungan Keluarga terhadap Motivasi Pasien Kanker Payudara dalam Menjalani Kemoterapi di Ruang Cendrawasih 1 RSUD Arifin Achmad Provinsi Riau. Jurnal NERS Indonesia, Vol.2 No.2, 2012. https://ejournal.unri.ac.id Smeltzer, S. C., \& Bare, B. G. 2010. Keperawatan Medikal Bedah. Jakarta: EGC.

Stuart \& Sundeen. 2002. Buku Saku Keperawatan Jiwa. Edisi III. Jakarta: EGC.

Suharmilah. 2013. Faktor-faktor yang Berhubungan dengan Tingkat Depresi pada Pasien Kanker Payudara yang Sudah Mendapatkan Terapi di Rumah Sakit Margono Soekarjo Purwokerto. Mandala of Health. Volume 6, Nomor 1, Januari 2016. 
Tjindarbumi. 2004. Penanganan Kanker Payudara Masa Kini dengan berbagai Macam Isu di Indonesia. Proceeding Indonesian Issues on Breast Cancer; Surabaya.
Wirawan. 2008. Budaya dan Iklim Organisasi. Jakarta: Salemba Empat.

WHO. 2013. World Health Statistic. www.who.int. 